\title{
FLORA I FAUNA KOSMICZNA STANISŁAWA LEMA W PRZEKŁADZIE NA JĘZYK ANGIELSKI
}

\section{Abstract \\ Stanisław Lem's Space Flora and Fauna Translated into English}

The article discusses authorial neologisms coined by Stanislaw Lem and their translation into English on the example of 37 plant and animal names excerpted from the short story entitled Let Us Save the Universe (An Open Letter from Ijon Tichy), which, together with their English equivalents, were subject to comparative analysis. Since these names may create translation problems, the purpose of the analysis was primarily to determine the problem-solving techniques used by the translators, Maria Święcicka-Ziemianek and Joel Stern. Another goal was to make an attempt at explaining their translation choices and to determine the impact of these choices on the way in which the equivalents expressed with neologisms perform their naming function and the function through which they create the narrative world in the target text. Therefore, the article lists the possible causes of translation problems evoked by neologisms and presents the characteristics of the analysed names in terms of translation difficulties they may pose. The analytical material is presented taking into account the relationship between neologisms and their equivalents with the accompanying context and/or illustration. The article provides conclusions on the impact of the techniques used and the elements that determined the final shape of equivalents on the way the naming and creative function of authorial neologisms are reflected in the target text. It also shows the methods of overcoming problems related to translating neologisms into a foreign language.

Keywords: literary translation, authorial neologism, translation techniques, science fiction literature.

Słowa kluczowe: przekład literacki, neologizm autorski, techniki tłumaczenia, literatura fantastycznonaukowa. 


\section{Wprowadzenie}

W literaturze translatorycznej często podkreśla się fakt, iż neologizmy autorskie, czyli, najogólniej rzecz ujmując, nowe wyrazy ukute przez autora na potrzeby danego utworu (por. Skubalanka 1962: 43; Dziwisz 2013: 120; por. Goral 2015: 301), stanowią jeden z elementów tekstu wyjściowego nastręczających thumaczom trudności przekładowych (Hejwowski 2009: 113; Pleciński 2010: 146; Skibińska, Rzeszotnik 2010: 287-300). Główną przyczyną tych trudności jest bezekwiwalentny charakter neologizmów, który stwarza konieczność podejścia do ich przekładu w sposób jeszcze bardziej twórczy i kreatywny, niż w wypadku wyrazów zleksykalizowanych posiadających już odpowiedniki w innych językach (Hejwowski 2009: 112, 113; Pleciński 2010: 147, 148). Tłumacz, chcąc oddać neologizm neologizmem - co jest w zgodzie z zasadą postulowaną przez teoretyków przekładu (por. Newmark 1988: 149; Hejwowski 2009: 113) - poza umiejętnościami interpretowania tekstu wyjściowego i korzystania z różnego rodzaju źródeł wiedzy językowej, ogólnej i specjalistycznej, musi wykazać zdolności słowotwórcze oraz dużą pomysłowość w tym zakresie (por. Hejwowski 2009: 113; Pleciński 2010: 147, 148). Jeśli chodzi o szczegółowe przyczyny trudności przekładowych powodowanych przez neologizmy autorskie, to choć są różnorodne, bo zawsze motywowane konkretnym utworem literackim (Skibińska, Rzeszotnik 2010: 287-300), wynikają one na ogół z cech samych neologizmów, które wypada odzwierciedlić w przekładzie. Składają się na nie nietypowość ich formy i różnorodność typów, czytelność i nieczytelność oraz liczebność, rozmieszczenie i zagęszczenie. Do tego dochodzą relacje, jakie neologizmy tworzą z pozostałymi elementami utworu, czyli głównie relacje z kontekstem oraz relacje z przedstawiającymi je ilustracjami, a także funkcje, jakie pełnią w danym tekście literackim - na przykład funkcja nazewnicza czy też funkcja kreowania fantastycznego świata przedstawionego (Handke 1989), których dotyczy analiza translatoryczna zaprezentowana $\mathrm{w}$ tym artykule - i stopień ich produktywności w zakresie ich realizowania. Celem tej analizy jest określenie, czy ekwiwalenty pełnią wspomniane funkcje w ten sam sposób co neologizmy autorskie (wyjściowe), a jeśli nie, to z jakich przyczyn.

Będące przedmiotem analizy neologizmy ukute przez Stanisława Lema na potrzeby opowiadania Ratujmy kosmos (List otwarty Ijona Tichego), należącego do cyklu opowiadań o wspomnianym w tytule bohaterze, można rozpatrywać pod kątem wszystkich wymienionych powyżej cech, relacji 
oraz funkcji jako kryteriów, które należy uwzględnić w procesie przekładu. Jeśli chodzi o ich cechy, uwagę czytelnika zwraca w pierwszej kolejności nietypowość tych nowych nazw. Opowiadanie Ratujmy kosmos... jest, jak wskazuje jego pełny tytuł, listem otwartym Ijona Tichego do społeczności międzyplanetarnej, w którym stara się on zwrócić jej uwagę na negatywne konsekwencje „turystyki kosmicznej”, w tym przede wszystkim jej wpływ na życie w Wielkim Rezerwacie. Większość neologizmów to zatem dziwaczne nazwy zagrożonych, wymierających bądź już wymarłych przedstawicieli flory i fauny kosmicznej, wzorowane na autentycznych, nierzadko równie zaskakujących, nazwach wernakularnych (zwyczajowych) zwierząt - takich jak chociażby „lśniś nawapnik” (pająk) albo „zdradnica śmiercionośna” (wąż) - i roślin, takich jak ,groszek niepozorny” (kwiat) albo „psianka słodkogórz" (kwiat). Stąd neologizmy, podobnie jak i nazwy, na których mogły być wzorowane ${ }^{1}$, składają się na ogół z dwóch wyrazów, choć autor, nie ograniczył się tylko do jednego typu neologizmu - kwestia typów neologizmów zostanie poruszona w dalszej części artykułu podczas omawiania konkretnych przykładów, ponieważ jest istotna w kontekście analizowania trudności tłumaczeniowych oraz funkcji kreacyjnej i jej odzwierciedlenia w tekście docelowym². Poszczególne typy neologizmów - neologizmy absolutne (nieprzypominające wyrazów pospolitych, a jeśli już, to w bardzo ograniczonym stopniu, uniemożliwiającym rozpoznanie podstawy słowotwórczej, czyli wyrazu motywującego, tj. wyrazu, od którego zostały utworzone), strukturalne (przypominające wyrazy pospolite i powstałe w drodze typowych procesów słowotwórczych), semantyczne (istniejące wyrazy użyte w nowym, innym niż powszechnie przyjęte, znaczeniu, które wyjaśnia jedynie kontekst utworu), kolokacyjne (nietypowe zestawienia wyrazowe) (por. Handke 1989: 233-235, 238, 240, 243; Hejwowski 2009: 112; Stockwell 2000: 112-118) i mieszane (rozmaite hybrydy wymienionych wcześniej typów, np. neologizmy kolokacyjne będące zestawieniami neologizmu absolutnego i strukturalnego, wyrazu pospolitego i dwóch neologizmów strukturalnych) - różnią się między sobą produktywnością w zakresie kreowania fantastycznego świata i stopniem, w jakim wywołują wrażenie obcości (Handke 1989: 238, 243), której są nośnikami (Suvin

${ }^{1}$ Być może były wzorowane na bliżej nieokreślonych nazwach zwyczajowych lub na nazwach zaprezentowanych w konkretnych źródłach - Anna Baranowa (2008: 115) przedstawia bardzo ciekawą hipotezę, zgodnie z którą nazwy te mogły być motywowane nazewnictwem zoologicznym prezentowanym w książkach Emila Wyrobka.

${ }^{2}$ Nie będzie jednak stanowiła punktu wyjścia do pogrupowania materiału badawczego. 
1979). Im bardziej przypominają istniejące wyrazy i im więcej o nich wiadomo z kontekstu, tym większa jest ich produktywność w zakresie kreowania świata przedstawionego. $Z$ kolei im mniej je przypominają, tym większe jest wrażenie obcości, jakie wywołują; przy czym jeśli jest ono zbyt wysokie, wówczas neologizmy nie są produktywne kreacyjnie (nie pozwalają czytelnikowi wyobrazić sobie czegokolwiek na ich temat), dlatego w literaturze fantastycznonaukowej najwięcej jest neologizmów strukturalnych i kolokacyjnych, a najmniej absolutnych i semantycznych (Handke 1989: 238, 239, 243). Jednocześnie neologizmy absolutne są najłatwiejsze do przetłumaczenia na język obcy, podczas gdy neologizmy strukturalne i semantyczne mogą sprawiać najwięcej trudności, ponieważ w znacznym stopniu ograniczają swobodę tłumacza (Pleciński 2010: 148).

\section{Wstępna charakterystyka analizowanych neologizmów autorskich}

Neologizmy odnoszące się do zwierząt i roślin - za pomocą których autor uprawdopodobnił fantastyczny świat (por. Hejwowski 2009: 113) w opowiadaniu Ratujmy kosmos... są nie tylko nietypowe i różnorodne, ale też bardzo liczne, co dodatkowo wzmaga wrażenie obcości - nazywają 37 elementów świata przedstawionego (por. Krajewska 2006), z czego 13 ma dodatkowo synonimy, które udają nazwy naukowe (łacińskie), a trzeba pamiętać, że nie są to jedyne neologizmy w tym krótkim, kilkunastostronicowym utworze, zawierającym pokaźnych rozmiarów ilustracje ( $5 \mathrm{w}$ wydaniu polskim z 2008 roku i 8 w pierwszym wydaniu angielskim z 1982 roku). Potwierdza to tezę Petera Stockwella, zgodnie z którą większej liczby neologizmów autorskich można się spodziewać w krótszych formach literackich tego typu (2000: 108), i prowadzi do obserwacji, że analizowane tu neologizmy charakteryzują się dużym zagęszczeniem. Zagęszczenie to jest różne w zależności od fragmentu utworu i zależy od rozmieszczenia neologizmów w jego obrębie - w opowiadaniu Ratujmy kosmos ... pojawiają się fragmenty, gdzie „następuje gwałtowna kondensacja neologizmów”, o której pisze Krzysztof Hejwowski (2009: 114, 115), na przykład fragment dotyczący innych przedstawicieli flory i fauny (zob. Lem 2008: 145; Lem 1982: 151). Krzysztof Hejwowski (2009: 114, 115) wskazuje takie fragmenty jako miejsca, które - choć skomplikowane pod względem przekładowym - pozwalają tłumaczowi wykazać się pomysłowością, czasami nawet nadmierną. 
Wracając do zasygnalizowanych powyżej typów neologizmów, wiąże się z nimi kwestia czytelności nazwy poza kontekstem (por. Handke 1989: 234, 237, 238, 241). Czytelność ta bywa różna, również dla analizowanych w tym artykule nazw - na przykład neologizm mrówka krzesławka dręczypupa zdradza czytelnikowi bardzo dużo, przede wszystkim informuje, że jej desygnat jest owadem, podczas gdy z nazwy warłaj modry nie da się odczytać wielu szczegółów. Im mniej szczegółów dana nazwa zdradza, tym więcej generuje ona hipotez na temat jej znaczenia, które weryfikuje się na podstawie dodatkowych informacji, na przykład kontekstu, jeśli takie są dostępne (por. Handke 1989: 234) - o wartaju modrym kontekst milczy do tego stopnia, że nie wiadomo, czy jest on zwierzęciem, czy rośliną, podczas gdy mrówka krzesławka dręczypupa została w nim opisana bardzo szczegółowo. Dodatkowe informacje mogą też zostać ujawnione czytelnikowi za pośrednictwem ilustracji, czyli znaków wyrażonych innym kodem (ikonicznym) (por. Kaźmierczak 2017: 17, 18). W przekładzie opowiadania Ratujmy kosmos ... ilustracja towarzyszy ośmiu neologizmom, które zostaną wymienione i wyróżnione graficznie w dalszej części artykułu - wszystkie z nich odnoszą się do zwierząt. Biorąc pod uwagę relację, jaka może zaistnieć pomiędzy neologizmem a jego opisem kontekstowym w ramach pełnienia przez obydwa środki językowe funkcji kreacyjnej, tj. przesunięć na linii neologizm-kontekst, kontekst-neologizm (Handke 1989: 234, 238, 241), orazw drodze analogii - również relację pomiędzy neologizmem a ilustracją, jak również relację pomiędzy neologizmem, ilustracją i kontekstem, można się spodziewać, że w zależności od tego, czym był motywowany ekwiwalent (neologizmem wyjściowym, jego opisem kontekstowym, ilustracją, czy ich kombinacją), w przekładzie może dojść do pewnych przesunięć na linii neologizm wyjściowy-kontekst/ilustracja, a tym samym do zmian w sposobie, w jaki ekwiwalenty kreują świat przedstawiony w tekście przekładu³.

3 W celu dokładnego prześledzenia tych przesunięć i ustalenia sposobu, w jaki ekwiwalenty realizują funkcję kreacyjną w tekście docelowym, przykłady omawiane w tym artykule (zaprezentowane szczegółowo w częściach 4-8) pogrupowano ze względu na to, czym motywowane były odpowiedniki, tj. ilustracją, wszystkimi lub wybranymi komponentami neologizmu autorskiego (wyjściowego), opisem kontekstowym czy też kombinacją wymienionych. Oczywiście istnieją też odpowiedniki o niejasnej motywacji i te zostaną omówione osobno (część 9). 


\section{Neologizmy autorskie i ich przekład na język angielski - uwagi ogólne}

Przekład neologizmów w opowiadaniu Ratujmy kosmos mógł więc być wyzwaniem dla jego angielskich tłumaczy - Joela Sterna i Marii Święcickiej-Ziemianek ${ }^{4}$ - ponieważ wymagał uwzględnienia zasygnalizowanych powyżej kwestii. Neologizmy, o których mowa, obejmowały nazwy gatunków zwierząt, w tym: 1) drapieżników: czajaki polkliwe [swallurkers] ${ }^{5}$, wędłowiec [herpeton]; 2) owadów: mrówka krzeslawka dręczypupa [bottombiter chair ant], przebizad uporek [drillbeaked borbit] ${ }^{6}$; 3) członkonogich: moczyścier przeprzaśny [scrooch], rzęsula niedołazka [fripples], woczykij brutalik [brutalacean rollipede]; 4) gadów: przewrotnik podstawiec [trippersneak], wężonóg teleskopek [the snakefooted telescoper]; 5) ptaków: pismaczek przedrzeźniaczek, pismaczek przedrzeźniak [scribblemock]; 6) innych zwierząt: fetorówka obrzydlnica [foul-tailed fetido], zmyłek oczajduszny [deadly deceptorite], mściwiec bezdrożnik [vengerix], ostrobodziec tyłowtoki [spiny slothodile], rozkęs przytajnik [morselone], wyjec elektryczny [electric howler], zatapiacz bulgotny [maraudola]. Natomiast neologizmy nazywające rośliny kosmiczne obejmowały nazwy: 1) zarośli: cieplaki [warmstrels], zimniaki [chillips]; 2) drzew: cichlust [solinthia], miażdzyca kamienula [brainbasher]; 3) ziół: krotowrzask [yellwort]; 4) innych roślin: echoń pyskatek [echoloon], goryczka rozumna [sentient gentian], goryczka szalona [crazy gentian], okrucytia cudawka [cruella], pasowa róża [crimson rose $]^{7}$, wściektoja [furiol]. Poza nazwami, co do których na podstawie

${ }^{4}$ Przekład ten, zatytułowany Let Us Save the Universe (An Open Letter from Ijon Tichy) ukazał się w 1981 roku nakładem wydawnictwa Harcourt Brace Jovanovich (HBJ) w zbiorze Memoirs of a Space Traveler. Further Reminisceneces of Ijon Tichy. Zbiór ten zawiera thumaczenia wybranych opowiadań wchodzących w skład Dzienników gwiazdowych wydanych nakładem Czytelnika w roku 1971. Wybór pozostałych tłumaczeń opowiadań z tego samego, czwartego wydania Dzienników..., w tym większości Podróży, jest dostępny w zbiorze pt. The Star Diaries. Autorem przekładów zamieszczonych w The Star Diaries jest Michael Kandel.

${ }^{5} \mathrm{~W}$ tej części artykułu pogrubieniem zaznaczono neologizmy, którym w wersji angielskiej towarzyszy ilustracja. Są to wyłącznie neologizmy odnoszące się do fauny.

${ }^{6}$ O tym, że przebizad uporek jest owadem przypominającym chrząszcza, wyposażonym w wiertło zamiast aparatu gębowego, czytelnik dowiaduje się wyłącznie z ilustracji, ponieważ kontekst nie doprecyzowuje znaczenia tego neologizmu.

7 Zestawienie pasowa róża jest neosemantyzmem, ponieważ w opowiadaniu roślina ta zyskała nowe cechy - żyje na ogonie wędłowca, stanowiąc wabik na turystów, których najpewniej pożera. 
kontekstu lub ilustracji nie ulega wątpliwości, że odnoszą się do roślin lub zwierząt, występują też ,inne okazy flory i fauny”, w tym: ćpacz smakowniczek [geekling], drwacz wyprzastek brzeszczozgrzębny $[-]^{8}$, mordelia wyżwawka [carnivamp], pośladkówka otwornica [dementeria], rozrabień wrzaskotek [-], trupawka niedoćmawka [marshmucker], tryblas druzgotek [saprophoid], wartaj modry [blue wizzom] i wszechjadek bylepas [-]. Jak już wspomniano, przy niektórych z powyższych nazw udających wernakularne (zwyczajowe) pojawiają się nazwy stylizowane na łacińskie. Sytuacja ta dotyczy następujących nazw (podanych w kolejności chronologicznej): mrówka krzesławka dręczypupa (Multipodium pseudostellatum Trylopii), wężonóg teleskopek (Anencephalus pseudoopticus tripedius Klaczkinensis), przewrotnik podstawiec (Serpens vitiosus Reichenmantlii), okrucytia cudawka (Pliximiglaquia bombardans L.), pąsowa róża (Rosa mendatrix Tichiana), goryczka rozumna (Gentiana sapiens suicidalis Pruck), goryczka szalona (Gentiana mentecapta), pismaczek przedrzeźniak (Graphomanus spasmaticus Essenbachii), cieplak odmiany barowej (Thermomendax spirituosus halucinogenes), drwacz wyprzasek brzeszczozgrzębny (Gauleiterium Flagellans), rozrabień wrzaskotek (Syphonophiles Pruritualis), stróżyczka pieścidławka (Lingula stranguloides Erdmenglerbeyeri), echoń pyskatek (Echolalium impudicum Schwamps). Podane w nawiasach nazwy - nawiązujące do „zwyczajowych” (np. poprzez użycie wyrazu sapiens w odniesieniu do goryczki rozumnej) lub częściej do dotyczących ich informacji kontekstowych (np. poprzez użycie wyrazu tripedius w odniesieniu do teleskopka, o którym wiadomo, że ma trzy nogi, wyrazu serpens w odniesieniu do przewrotnika podstawca, który jest wężem, czy też wyrazu halucinogenes w odniesieniu do cieplaków, które wytwarzają fatamorgany) - przetransferowano do tekstu docelowego, dzięki czemu realizują one funkcję kreacyjną w ten sam sposób co w tekście oryginału.

Wracając do nazw ,zwyczajowych”, uwagę przykuwa w pierwszej kolejności nietypowość sposobu, w jaki zostały sformułowane. Nazwy zwierząt to na ogół zestawienia dwóch neologizmów strukturalnych (np. czajaki połkliwe) - wyjątek stanowi neologizm absolutny wędłowiec i neologizm mieszany mrówka krzesławka dręczypupa (zestawienie dwóch neologizmów strukturalnych z wyrazem pospolitym). Nazwy roślin zostały w większości utworzone podobnie, ale można pośród nich zaobserwować większą

${ }^{8}$ Myślnik w nawiasie kwadratowym oznacza, że neologizm nie posiada odpowiednika w tekście przekładu. 
różnorodność typów neologizmów. Poza dominującymi zestawieniami neologizmów strukturalnych (np. rzęsula niedołazka), typy te obejmują również neosemantyzmy (pąsowa róża) i neologizmy kolokacyjne (goryczka rozumna, goryczka szalona). Uwagę zwraca też większa różnorodność neologizmów mieszanych (np. neologizm miażdżyca kamienula, będący zestawieniem neologizmu strukturalnego z semantycznym), oraz fakt, że pośród nazw roślin kosmicznych występuje więcej neologizmów jednowyrazowych (chodzi o neologizmy strukturalne zimniaki, cieplaki, cichlust, ktotowrzask, wściekłoja) niż pośród nazw zwierząt. Tłumacze starali się odzwierciedlić typy neologizmów w przekładzie, to znaczy tworzyć zestawienia wyrazowe podobne do oryginalnych, jednak da się zauważyć wyraźne zwiększenie liczby jednowyrazowych neologizmów odnoszących się do zwierząt (neologizmy strukturalne swallurkers, fripples, scrooch, trippersneak, scribblemock). W wypadku nazw roślin ekwiwalenty to już głównie neologizmy jednowyrazowe, wyjątek stanowią zestawienia crimson rose, sentient gentian i crazy gentian, z czego pierwszy to neosemantyzm, a dwa pozostałe to neologizmy kolokacyjne, tak jak w tekście oryginału. Podobne odwrócenie stosunku nazw dwu- i wielowyrazowych do nazw jednowyrazowych w przekładzie daje się zaobserwować również w wypadku nazw ,innych okazów flory i fauny", gdzie jedyne zestawienie to blue wizzom. Poza tendencją do zastępowania nazw dwuwyrazowych jednowyrazowymi, uwagę zwraca użycie techniki opuszczania neologizmów w tłumaczeniu, widoczne na przykładzie nazw drwacz wyprzastek brzeszczozgrzębny, rozrabień wrzaskotek i wszechjadek bylepas. Zastosowanie tej techniki w przekładzie literackim zasadniczo nie powinno mieć miejsca (por. Hejwowski 2015: 96), jednak decyzję tłumaczy da się wyjaśnić rozmieszczeniem wspomnianych neologizmów w tekście utworu - pojawiają się one w nagromadzeniu, we fragmencie, w którym następuje gwałtowna kondensacja neologizmów (zob. Lem 2008: 145; Lem 1982: 151). Skutki zastosowania techniki opuszczenia nie zawsze muszą być drastyczne - co można zilustrować na przykładzie neologizmów drwacz wyprzastek brzeszczozgrzębny i rozrabień wrzaskotek. Neologizmy te, jak już wspomniano, posiadają nazwy pseudołacińskie, które zostały przetransferowane do tekstu przekładu (jedna z tych nazw była dodatkowo opatrzona ilustracją, więc jej opuszczenie wymagałoby również usunięcia ilustracji ${ }^{9}$ ). Dzięki temu nie doszło do zubożenia świata

9 Usunięcie ilustracji nie byłoby zresztą zaskakujące. Z polskich wydań Dzienników... jedynie czwarte (z 1971 roku) jako pierwsze i jedyne zawierało wszystkie ilustracje w licz- 
przedstawionego o jego fantastyczne elementy, a jedynie do pomniejszenia zasobu nazw. Tego samego nie można powiedzieć o skutkach opuszczenia neologizmu wszechjadek bylepas, występującego w jednym zdaniu razem z pięcioma innymi neologizmami (ćpacz smakowniczek, mordelia wyżwawka, pośladkówka otwornica, trupawka niedoćmawa, tryblas druzgotek), których znaczenie nie zostało doprecyzowane w kontekście. Na szczęście opuszczenie tego neologizmu nie jest odczuwalne - ze względu na tak dużą kondensację neologizmów, przeciętny czytelnik raczej nie dostrzeże braku jednego $\mathrm{z}$ nich. Oznacza to, że tłumacze posługiwali się techniką opuszczenia bardzo ostrożnie. Co do pozostałych pięciu neologizmów, ten sam czynnik (kondensacja) oraz charakter ich relacji z kontekstem może wyjaśniać większą swobodę, na którą pozwolili sobie tłumacze i o której pisze Jacek Pleciński w odniesieniu do neologizmów absolutnych (2010: 148) - ekwiwalenty carnivamp, dementeria, geekling, marshmucker i saprophoid nie wykazują podobieństwa semantycznego do ich pierwowzorów (zostały ukute arbitralnie), podobnie zresztą jak ekwiwalenty fripple i scrooch, będące odpowiednikami neologizmów rzęsula niedołazka i moczyścier przeprzaśny, które pojawiły się w okolicznościach podobnych do opisanych powyżej (zob. Lem 2008: 138; Lem 1982: 144), w towarzystwie jeszcze jednego neologizmu.

\section{Ekwiwalenty motywowane ilustracjami}

Neologizm, o którym mowa - woczykij brutalik - przetłumaczono ekwiwalentem brutalacean rollipede. Drugi człon tego zestawienia dwóch neologizmów strukturalnych - neologizm rollipede (ang. roll - toczyć się; ang. centipede - stonoga) - może również wydawać się ukuty arbitralnie, ale w rzeczywistości nawiązuje do ilustracji wykonanej przez autora. Pierwowzór tego ekwiwalentu, neologizm woczykij brutalik, jest, podobnie jak ekwiwalent, zestawieniem dwóch neologizmów strukturalnych, z których pierwszy może się kojarzyć ze sformułowaniem „kij w oczy” (konotacja ta nie jest możliwa do odczytania w nazwie docelowej), a drugi z wyrazami „brutal” i „brutalny” (podobne skojarzenia wywołuje jego odpowiednik

bie 25 - kolejne zawierają ich mniej (Baranowa 2008: 112). Mniej zawiera ich również angielski przekład wydania czwartego, jeśli potraktować tomy Memoirs of a Space Traveler... i The Star Diaries jako komplet - można się w nim doliczyć łącznie 20 ilustracji. 
„brutalacean”). Omawiany neologizm wyjściowy nie jest opisany w kontekście, ale został opatrzony ilustracją autora, przedstawiającą postać podobną do centaura, który w odróżnieniu od niego jest hybrydą człowieka i czołgu, poruszającą się na gąsienicach, trzymającą w dłoni ostro zakończony kij. Podobna sytuacja dotyczy neologizmu przebizad uporek (od „przebijać”, „zad”, „upór”), który odnosi się do owada przypominającego chrząszcza, $\mathrm{z}$ aparatem gębowym w postaci wiertła, co wiadomo wyłącznie z ilustracji (zob. Lem 1982: 152) - czytelnikowi wersji polskiej trudno bez niej ustalić, czy desygnat w ogóle jest zwierzęciem. Ekwiwalent drillbeaked borbit oddaje wprawdzie znaczenie tylko jednej z możliwych podstaw neologizmu autorskiego (ang. bore - przebijać, wiercić, drążyć, świdrować, przekopywać) za pomocą drugiego członu, ale za to w bardzo ciekawy sposób nawiązuje do ilustracji za pomocą pierwszego z nich (drillbeaked). W tym wypadku relacja ekwiwalent-ilustracja przypomina relację neologizmkontekst, o której pisze Ryszard Handke (1989: 234) - czytelnik przekładu konfrontuje wstępne pomysły na temat możliwych znaczeń neologizmu strukturalnego z ilustracją, która ostatecznie to znaczenie doprecyzowuje ${ }^{10}$. Wynika to z faktu, że neologizm drillbeaked został utworzony od wyrazów drill i beak, z których pierwszy oznacza świder lub wiertło (co stanowi nawiązanie do ilustracji), natomiast drugi może się faktycznie odnosić do aparatu gębowego chrząszcza, jak również jego odpowiednika u innego zwierzęcia, ale w pierwszej kolejności przywodzi na myśl ptasi dziób.

Wpływ ilustracji na ostateczny kształt ekwiwalentu widać też w wypadku neologizmów, które zostały opisane w kontekście, i to w sposób dokładny. Za przykład może tu posłużyć neologizm fetorówka obrzydlnica. Nazwa tego zwierzęcia nie podpowiada cech ujawnionych dopiero w kontekście, z którego można się dowiedzieć, że wydziela ona nieprzyjemną woń (zasugerowany $\mathrm{w}$ nazwie obrzydliwy fetor) w wyniku odruchu obronnego (,refleks soczewkowo-podogonowy”), kiedy się ją fotografuje. Przytoczony tu kontekst nie wskazuje jednoznacznie, którędy wydobywa się przykra woń - można to ustalić dopiero na podstawie towarzyszącej nazwie ilustracji przedstawiającej zwierzę otoczone oparami wydobywającymi się z ogona (zob. Lem 2008: 147; Lem 1982: 150). Ekwiwalent foul-tailed fetido, będący zestawieniem neologizmów strukturalnych foul-tailed (ang. foul - m.in.

${ }^{10}$ Relacja neologizm-ilustracja wygląda inaczej w tekście oryginału - jego czytelnik, bez wstępnych pomysłów dotyczących możliwych znaczeń tego neologizmu, będzie raczej zaskoczony, że przebizad uporek wygląda tak, jak go zaprezentowano na ilustracji. 
obrzydliwy, cuchnący; ang. tail - ogon) i fetido (ang. fetid - cuchnący), oddaje znaczenia zasugerowane w nazwie, dobrze nawiązując przy tym do kontekstu i ilustracji, jednak - ze względu na obecność komponentu -tailedujawnia czytelnikowi dużo więcej niż neologizm autorski.

Ekwiwalent może być $\mathrm{w}$ jakimś stopniu motywowany również ilustracją odnoszącą się do innego neologizmu niż ten thumaczony. Tego typu wniosek można powziąć na podstawie tłumaczenia neologizmu ostrobodziec tyłowłoki odpowiednikiem spiny slothodile. Pierwszy człon ekwiwalentu, wyraz pospolity spiny (zool. kolczasty), nawiązuje do podstaw neologizmu strukturalnego ostrobodziec (ostry, bóść, ubóść), a drugi stanowi próbę oddania neologizmu strukturalnego tyłowłoki - który prawdopodobnie skojarzył się thumaczom ze sformułowaniem ,wlec się w tyle” - poprzez użycie podstawy słowotwórczej sloth (opieszałość, lenistwo, jak również leniwiec, szczerbak) oraz podstawy crocodile (krokodyl), dobranej pozornie arbitralnie - pozornie, ponieważ jej użycie może być, i najprawdopodobniej jest, nawiązaniem do ilustracji przedstawiającej zupełnie inne zwierzę, a konkretnie czajaka połkliwego (zob. Lem 1982: 142), na której przypomina on krokodyla o rozwartej paszczy hipopotama. Tłumaczenie nazwy jest tym bardziej zgrabne, że współgra ono z kontekstem - ostrobodziec według opisu autora, podobnie jak krokodyl, jest jajorodny. Czytelnik przekładu może więc odnieść wrażenie, że czajak i ostrobodziec są do siebie podobne - o pomyleniu tych dwóch reprezentantów fauny kosmicznej podczas lektury nie może być jednak mowy, ponieważ pod każdą ilustracją znajduje się angielska nazwa prezentowanego zwierzęcia (w polskim wydaniu z 2008 roku podpisane zostały tylko wybrane ilustracje).

\section{Ekwiwalenty motywowane wszystkimi komponentami neologizmów autorskich}

Co do ekwiwalentu neologizmu czajak połkliwy - który został nie tylko narysowany, ale też dość precyzyjnie opisany przez autora - w jego tłumaczeniu wykorzystano ekwiwalenty podstaw słowotwórczych obu członów zestawienia oryginalnego, tj. angielskie wyrazy swallow (połykać) i lurk (czaić się), do utworzenia neologizmu strukturalnego swallurker. Tej samej techniki użyto w przekładzie innego neologizmu, opatrzonego ilustracją i jeszcze obszerniejszym opisem, $\mathrm{tj}$. neologizmu pismaczek przedrzeźniaczek (zob. Lem 2008: 143; Lem 1982: 147), kojarzącego się z wyrazem „,pismak” 
(ang. hack, newshawk, newshound), pogardliwym określeniem dziennikarza, i wyrazem ,przedrzeźniacz” (ang. mimic, mocker), który może się odnosić do osoby przedrzeźniającej kogoś (użycie potoczne), do konkretnego gatunku ptaka (przedrzeźniacz północny, łac. Mimus polyglottos, ang. northern mockingbird) lub rodziny ptaków (przedrzeźniacze, łac. Mimidae, ang. mimids). Ekwiwalent scribblemock też może się kojarzyć z gatunkiem ptaka - przez podobieństwo do wyrazu peacock (paw) - dlatego dobrze nawiązuje do ilustracji i opisu kontekstowego informujących czytelnika, że pismaczek faktycznie jest ptakiem. Ekwiwalentów podstaw słowotwórczych użyto również w przekładzie neologizmu wężonóg teleskopek (wąż - snake; nogaleg, foot; teleskop - telescope), pozbawionego ilustracji, lecz opisanego w kontekście. W tym wypadku ekwiwalent snakefooted telescoper, bazujący na odpowiednikach podstaw słowotwórczych obu członów zestawienia, podobnie jak neologizm wyjściowy nie zdradza informacji kontekstowej.

Do wiernego odwzorowania zestawień w tekście przekładu tłumacze posługiwali się też ekwiwalentami słownikowymi obu ich członów. Zastosowanie tej techniki miało miejsce w wypadku neologizmu mieszanego wyjec elektryczny [electric howler], neologizmu semantycznego pasowa róża [crimson rose] oraz neologizmów kolokacyjnych goryczka rozumna [sentient gentian] i goryczka szalona [crazy gentian]. Ich ekwiwalenty, z wyjątkiem jednego, realizują funkcję kreacyjną tak samo jak nazwy oryginalne. Wyjątek, o którym mowa, to ekwiwalent electric howler, który odnosi się do zwierzęcia zagłuszającego dźwięki rock and rolla, a nie jazzu, tak jak to było w oryginale. W tym wypadku zmiana dotycząca sposobu, w jaki ekwiwalent realizuje funkcję kreacyjną, nie wynika z techniki przekładowej zastosowanej do nazwy, lecz z modyfikacji wprowadzonej w kontekście.

\section{Ekwiwalenty motywowane wybranymi komponentami neologizmów autorskich}

Zdarzały się jednak przypadki zastosowania kombinacji technik, polegających na wykorzystywaniu odpowiedników podstaw słowotwórczych do przetłumaczenia wybranych komponentów neologizmów, podczas gdy pozostałe były tłumaczone przy użyciu innych technik. Jedną z tych technik było opuszczenie komponentu neologizmu. Jej zastosowanie ilustruje przekład neologizmu okrucytia cudawka neologizmem cruella, utworzonym od wyrazu cruel (okrutny, bezlitosny, bolesny) i pomijającym cudowność 
kwiatów tej rośliny jako mniej istotną informację, wciąż możliwą do odczytania z jej opisu. Przykładem zastosowania tej techniki jest też tłumaczenie nazwy mściwiec bezdrożnik (od „mściwy”, „,bezdroża”) odpowiednikiem vengerix (od ang. revenge - zemsta; łac. -ix, sufiks spotykany w nazwach roślin i zwierząt).

Neologizmom docelowym cruella i vengerix nie można wprawdzie wiele zarzucić, ale zastosowanie kombinacji ekwiwalentu słownikowego podstawy słowotwórczej i opuszczenia prowadzi czasem do zaskakujących rezultatów, czego przykładem jest tłumaczenie jednowyrazowego neologizmu strukturalnego wściekłoja. Neologizm ten, jak już wspomniano, odnosi się do rośliny, jednak kontekst nie wskazuje, do jakiej konkretnie - ze względu na wyraźne podobieństwo neologizmu do wyrazu ,sekwoja” (ang. sequoia, redwood) można zakładać, że jest on nazwą drzewa. W tym kontekście wydaje się, że ekwiwalent wyzyskujący najbardziej oczywisty odpowiednik drugiej podstawy słowotwórczej (wściekłość - rage, fury; wściekły - furious, mad, raging), tj. neologizm furiol, nie współgra z kontekstem, ponieważ ze względu na przyrostek -ol przypomina raczej nazwę substancji chemicznej ze świata „Kongresu futurologicznego” niż rośliny.

Jak wspomniano wcześniej, podczas gdy część komponentów oryginalnej nazwy tłumaczono ekwiwalentami ich podstaw słowotwórczych. pozostałe mogły być tłumaczone przy użyciu innych technik. Za przykład może tu posłużyć tłumaczenie neologizmu mieszanego mrówka krzesławka dręczypupa, będącego zestawieniem wyrazu pospolitego „mrówka” (ang. ant) i neologizmów strukturalnych utworzonych odpowiednio od wyrazów „krzesło” (ang. chair), „dręczyć” (ang. torment, plague, nag) i ,pupa” (ang. bottom). Neologizm autorski został dość precyzyjnie opisany w kontekście i towarzyszy mu ilustracja (zob. Lem 2008: 139; Lem 1982: 143), na której liczne mrówki tworzą fotel. Ekwiwalent, neologizm bottombiter chair ant, oddaje znaczenie wszystkich komponentów, jednak w jednym przypadku da się zauważyć zastosowanie hiponimu - nazwa angielska objaśnia, w jaki sposób mrówki dręczą swoje ofiary (ang. bite - gryźć), choć kontekst oryginału o tym milczy.

W ramach stosowania kombinacji technik użyciu ekwiwalentu podstawy słowotwórczej mogło towarzyszyć zastąpienie jednego z komponentów innym, dobranym arbitralnie, tak jak w przypadku neologizmu echoń pyskatek [echoloon]. Neologizm ten, utworzony od wyrazów „echo” i ,pyskować”, odnosi się najprawdopodobniej do rośliny - o desygnacie tej nazwy wiadomo, że rośnie pod wpływem dźwięków dobiegających z otoczenia, 
najczęściej przekleństw turystów, co tłumaczy obecność drugiego członu. Został on przetłumaczony komponentem -loon, który może wywoływać skojarzenia z gatunkiem ptaka (ang. loon - nur) lub wyrazem loony (pomylony, wariat). Przykładem zastosowania tej kombinacji technik jest również tłumaczenie neologizmu rozkęs przytajnik, utworzonego od wyrazów „kęsek” i ,tajny. Jego ekwiwalent (morselone) oddaje znaczenie jednej z podstaw (ang. morsel - kęsek, kawałek, smakołyk) i jednocześnie przypomina wyraz chelone odnoszący się do żółwika, rośliny z rodziny babkowatych, jednak kontekst, tak jak w wypadku neologizmu wyjściowego, doprecyzowuje jego znaczenie.

\section{Ekwiwalenty motywowane wybranymi komponentami neologizmów autorskich i kontekstem}

Pojawiły się też takie ekwiwalenty, których jeden komponent został przetłumaczony odpowiednikiem podstawy słowotwórczej, a drugi wymieniony na inny, przy czym decyzja o zastosowaniu komponentu pozbawionego związku semantycznego z nazwą oryginalną była motywowana kontekstem. Sytuacja taka miała miejsce w przekładzie neologizmu zmyłek oczajduszny, utworzonego od wyrazów ,zmylić” i „oczajdusza”, odnoszącego się do hultaja lub hulaki. Ekwiwalent deadly deceptorite, wyzyskujący wyraz deceive (oszukiwać, okłamywać) jako podstawę drugiego członu, oddaje tylko jedno z możliwych znaczeń wyrażonych neologizmem autorskim. Jego pierwszy człon, aliteracyjny w stosunku do drugiego wyraz deadly (śmiertelny, śmiercionośny), znajduje natomiast umocowanie w kontekście - zmyłek jest zwierzęciem przypominającym drogowskaz, które kieruje turystów w przepaść, by następnie pożreć zwłoki ofiar, które wpadły w zasadzkę. Podobną procedurę można zauważyć na przykładzie neologizmu krotowrzask [yellwort], gdzie komponent złożenia został przetłumaczony dosłownie (wrzask - yell), a drugi został wymieniony na komponent -wort, pojawiający się w zwyczajowych nazwach roślin o właściwościach leczniczych (np. bellwort - jagodowiec, lungwort - miodunka). To samo dotyczy neologizmu cieplaki [warmstrels] - do przetłumaczenia podstawy słowotwórczej (ciepły - warm) użyto ekwiwalentu słownikowego i dodano komponent występujący między innymi w nazwach zwierząt latających (np. ang. kestrel - pustułka; ang. pipistrel - karlik), ponieważ cieplaki są roślinami wytwarzającymi miraże dostrzegalne w unoszącym się nad nimi 
ogrzanym powietrzu. Z nieco inną sytuacją mamy do czynienia w wypadku neologizmu zimniaki, który może wywoływać skojarzenia z wyrazami „zimno” i „ziemniaki” - o tym, że pierwsze skojarzenie jest prawidłowe, informuje czytelnika dopiero kontekst. Prawdopodobnie dlatego tłumacze zdecydowali się na ekwiwalent chillips, który oddaje znaczenie właściwej podstawy (ang. chill - zimno) i wprowadza nowe skojarzenie (ang. tulip tulipan), zmieniając charakter wyobrażenia.

Kolejna para - neologizm mieszany warłaj modry, który nie został opisany w kontekście, i jego ekwiwalent blue wizzom - ilustruje zastosowanie kombinacji ekwiwalentu motywowanego bardzo ogólną informacją kontekstową (,inny okaz" flory lub fauny) i hiperonimu. Pierwszy człon tego neologizmu może wywoływać skojarzenia z nazwą „wątlik charłaj” (odnoszącą się do owada) lub wyrazem „wartki”, a jego ekwiwalent (wizzom) z wyrazem „whiz” (m.in. brzęczeć, świszczeć, bzykać, gwizdać), podczas gdy drugi, odnoszący się do odcienia koloru niebieskiego, został przetłumaczony hiperonimem blue, co dobrze nawiązuje do autentycznych nazw zwyczajowych gatunków ssaków żyjących (np. dujkerczyk modry - blue duiker) i wymarłych (np. antylopowiec modry - bluebuck, blue antelope).

\section{Ekwiwalenty motywowane kontekstem}

Inne ekwiwalenty miały jeszcze mniej podobieństwa lub nie miały nic wspólnego z podstawami słowotwórczymi neologizmów autorskich, ale były motywowane kontekstem. Ilustruje to thumaczenie neologizmu przewrotnik podstawiec (od „przewracać”, ,podstawiać”), odnoszącego się do gada przyczajonego w krzakach i polującego na turystów, którym podstawia ogon z ukrycia, by następnie pożreć ofiarę, gdy ta się przewróci. Ekwiwalent trippersneak (od ang. tripper - turysta, wycieczkowicz; ang. trip - potknąć się, podstawić komuś nogę; ang. sneak - przemykać chyłkiem; ang. sneakily - podstępnie) zdradza inną niż nazwa wyjściowa informację wyjaśnioną w kontekście. Innym przykładem takiego ekwiwalentu jest neologizm brainbasher (ang. brain - mózg; ang. bash - trzasnąć, wyrżnąć, rozwalić) jako odpowiednik neologizmu miażdzyca kamienula, odnoszącego się do drzewa o owocach „rozmiarów dyni” w oryginale i „rozmiarów melona” w tekście przekładu, które spadają na turystę (zabijając go), jeśli zerwie kwiat okrucytii żyjącej z miażḋyca w symbiozie. 


\section{Ekwiwalenty o niejasnej motywacji (ukute arbitralnie)}

Trudno natomiast ustalić, czym były motywowane ekwiwalenty neologizmów wędłowiec i cichlust ${ }^{11}$. Ekwiwalent neologizmu absolutnego wędtowiec (tj. neologizm strukturalny herpeton), kojarzący się z wyrazem herpetology (herpetologia), sugeruje czytelnikowi, że wyraz ten odnosi się do gada, co nie jest prawdą, ponieważ o wędłowcu, który ma ogon i długie kły, wiadomo tylko tyle, że jest drapieżnikiem. Z kolei ekwiwalent neologizmu strukturalnego cichlust (od ,cichy”, „,chlustać”) - odnoszącego się do wysokiego drzewa, które może oślepić turystę, tryskając mu w oczy jadowitym sokiem, jeśli ten natnie jego korę - to neologizm strukturalny solinthia, kojarzący się z wyrazami solitary (samotny) i forsythia (forsycja).

\section{Wnioski}

Z powyższych obserwacji dotyczących przekładu nazw flory i fauny kosmicznej można wyprowadzić szereg wniosków. Po pierwsze to, czym jest motywowany dany ekwiwalent (neologizmem, kontekstem, ilustracją, czy ich kombinacją), nie musi wpływać, i w tym wypadku nie wpływa, na to, jak realizowana jest funkcja nazewnicza neologizmów w przekładzie. Ekwiwalenty, niezależnie od tego, czy doszło do przesunięć na linii neologizm-kontekst-ilustracja, nazywają w przekładzie dokładnie to samo co w oryginale, czyli rośliny, zwierzęta lub elementy, co do których nie wiadomo, czym dokładnie są - pewne wątpliwości może wzbudzać ekwiwalent furiol jako odpowiednik neologizmu wściekłoja, który tak jak w oryginale nazywa drzewo, ale nie najlepiej pasuje do tych celów. Innego rodzaju wątpliwości wywołują ekwiwalenty herpeton (odpowiednik neologizmu wędtowiec, który w dalszym ciągu odnosi się do zwierzęcia, ale sugeruje, że miałby on być gadem, wzbogacając tym samym świat przedstawiony o kolejnego) i chillips (ekwiwalent neologizmu cieplaki, wywołujący skojarzenia z kwiatami zamiast z krzewami) - ponieważ w rezultacie ich zastosowania

${ }^{11}$ Do tej grupy należy też zaliczyć neologizmy mordelia wyżwawka [carnivamp], pośladkówka otwornica [dementeria], trupawka niedoćmawka [marshmucker], tryblas druzgotek [saprophoid], moczyścier przeprzaśny [scrooch], rzęsula niedołazka [fripples] i zatapiacz bulgotny [maraudola], o których mowa w części 3 artykułu. 
wykreowane zostały elementy o innych niż oryginalne cechach. W pozostałych wypadkach różnice dotyczące sposobu prezentacji nazw (zwiększenie liczby nazw jednowyrazowych w tekście przekładu) nie miały wpływu na sposób, w jaki pełnią one funkcję nazewniczą - wyrażone neologizmami jednowyrazowe nazwy roślin i zwierząt wyglądają naturalnie. Taki sposób ich prezentacji ma jednak wpływ na kreację świata przedstawionego w tekście przekładu - odczuwane przez czytelnika wrażenie obcości zostaje zredukowane poprzez zmniejszenie liczby neologizmów strukturalnych, czyniąc tekst bardziej przystępnym i eliminując sytuację, w której zaproponowane ekwiwalenty jako zbyt dosłowne mogłyby być niezgrabne (por. Hejwowski 2009: 114). Do redukcji wrażenia obcości w tekście przekładu może też dojść w drodze zmniejszenia zasobu neologizmów poprzez ich opuszczanie, co zostało zilustrowane na przykładzie neologizmów rozrabień wrzaskotek i drwacz wyprzastek brzeszczozgrzębny. Zastosowanie tej techniki tłumaczeniowej w przekładzie neologizmów może doprowadzić nie tylko do wyeliminowania nazwy z tekstu, ale też do usunięcia ze świata przedstawionego elementu, do którego nazwa ta się odnosiła, co zostało pokazane na przykładzie neologizmu wszechjadek bylepas. Szerszy kontekst, w jakim doszło do omówionych w artykule opuszczeń (neologizmów lub ich komponentów), pokazuje jednak, że tłumacze najpewniej zdawali sobie sprawę z możliwych zagrożeń i konsekwencji zastosowania tej techniki przekładowej. Świadczy o tym fakt, iż używali jej oni oszczędnie i tylko w ostateczności, na ogół w kombinacji z inną techniką, po to, by ekwiwalenty wyrażone neologizmami brzmiały naturalnie (mowa o tworzeniu jednowyrazowych neologizmów strukturalnych w miejsce ich zestawień), a jeśli już postanowili opuścić dany neologizm lub jego komponent, czynili to bardzo ostrożnie, w miejscach, gdzie rezultaty tej decyzji byłyby najmniej odczuwalne, czyli we fragmentach o gwałtownej kondensacji neologizmów, gdzie tłumacze mogli sobie pozwolić na większą swobodę przekładową, tworząc neologizmy o niejasnej motywacji (fripples, scrooch; carnivamp, dementeria, geekling, maraudola, marshmucker, saprophoid). Zastosowanie techniki opuszczenia jako uzupełniającej może doprowadzić do redukcji wrażenia obcości, co ilustruje przekład neologizmu mściwiec bezdrożnik [vengerix], ale da się to zrównoważyć, jeśli doda się komponent, jakiego nie było w oryginale, sugerujący czytelnikowi znaczenie, które odrzuci, konfrontując nazwę z kontekstem (kontekst ujawnia, że ekwiwalent morselone odnoszący się do neologizmu rozkęs przytajnik nie jest rośliną, ale zwierzęciem), albo jeśli informacja dotycząca opuszczonych w przekładzie 
komponentów jest w dalszym ciągu możliwa do odczytania z kontekstu (tak jak w wypadku neologizmów okrucytia cudawka [cruella] i echoń pyskatek [echoloon], których ekwiwalenty zdradzają mniej informacji kontekstowej, przez co są bardziej obce).

Możliwe są też przesunięcia w drugą stronę - wówczas ekwiwalent wyrażony neologizmem zdradza dodatkowe informacje przedstawione w kontekście lub na towarzyszącej neologizmowi ilustracji, wobec czego jest bardziej rozpoznawalny. Tego typu redukcję wrażenia obcości można zaobserwować na przykładzie ekwiwalentów motywowanych:

1. ilustracją i wybranymi komponentami neologizmu wyjściowego, tj. przebizad uporek [drillbeaked borbit];

2. wybranymi komponentami neologizmu wyjściowego i ilustracją towarzyszącą innemu neologizmowi, tj. ostrobodziec tyłowłoki [spiny slothodile];

3. wybranymi komponentami neologizmu, ilustracją i kontekstem, tj.fetorówka obrzydlnica [foul-tailed fetido];

4. wybranymi komponentami neologizmu i kontekstem, tj. krotowrzask [yellwort];

5. wszystkimi komponentami neologizmu i kontekstem, tj. zimniaki [chillips], cieplaki [warmstrels].

Do redukcji wrażenia obcości nie dochodzi, jeśli informacja zasugerowana w nazwie i obecna na ilustracji została wymieniona na inną (rollipede zamiast woczykij) - to samo dotyczy niektórych ekwiwalentów motywowanych kontekstem, tj. miażdzyca kamienula [brainbasher], przewrotnik podstawiec [trippersneak] i zmyłek oczajduszny [deadly deceptorite]. Redukcji wrażenia obcości można też uniknąć, tłumacząc komponenty neologizmów wyjściowych za pomocą ich odpowiedników słownikowych (pąsowa różacrimson rose, goryczka rozumna - sentient gentian, goryczka szalona - crazy gentian, wyjec elektryczny - electric howler), odpowiedników słownikowych ich (możliwych) podstaw słowotwórczych (czajak połkliwy-swallurker, wężonóg teleskopek-snakefooted telescoper, pismaczek przedrzeźniak-scribblemock, warłaj modry - blue wizzom) oraz odpowiedników ich podstaw słowotwórczych użytych w kombinacji z hiponimem (mrówka krzesławka dręczypupa - bottombiter chair ant]. Podczas stosowania wspomnianych technik może jednak dojść do zmian w funkcji kreacyjnej, jeśli nastąpi ingerencja w opis kontekstowy, co zostało pokazane na przykładzie neologizmu wyjec elektryczny [electric howler]. 


\section{Bibliografia}

Baranowa A. 2008. Śmieszne i straszne. Rysunki Stanisława Lema. Na marginesie wystawy w Galerii dylag.pl. Kraków 13 marca - 26 kwietnia 2008, „Quart”, 2(8), s. $110-115$.

Dziwisz M. 2013. Językowe mechanizmy tworzenia autorskich neologizmów w utworach z gatunku fantasy (na przykładzie opowiadań Andrzeja Sapkowskiego), „Acta Humana" 4(1), s. 119-125.

Goral A. 2015. Neologizmy autorskie w powieści „Rzeczy uprzyjemniajace. Utopia” T. Bołdak-Janowskiej, „Studia Wschodniosłowiańskie”, 15, s. 299-313.

Handke R. 1989. Językowe sposoby kreowania sktadników fantastycznych, w: R. Handke, L. Jęczmyk, B. Okólska (red.), Spór o science fiction. Antologia szkiców i esejów o science fiction, Poznań: Wydawnictwo Poznańskie, s. 228-248.

Hejwowski K. 2015. Iluzja przekładu, Katowice: Śląsk.

- 2009. Kognitywno-komunikacyjna teoria przektadu, Warszawa: Wydawnictwo Naukowe PWN.

Kaźmierczak M. 2017. Od przekładu intersemiotycznego do intersemiotycznych aspektów tlumaczenia, „Przekładaniec”, 34, s. 7-35.

Krajewska M. 2006. Polsko-rosyjski stownik Lemowych neologizmów, Toruń: TNT.

Lem S. 2008. Ratujmy kosmos (List otwarty Ijona Tichego), w: S. Lem, Kongres futurologiczny: opowiadania Ijona Tichego, Warszawa: Agora, s. 135-148.

— 1982. Let Us Save the Universe (An Open Letter from Ijon Tichy), w: S. Lem, Memoirs of a Space Traveler: Further Reminiscences of Ijon Tichy, przeł. M. ŚwięcickaZiemianek, J. Stern, New York: Harcourt Brace Jovanovich, s. 139-153.

Newmark P. 1988. A Textbook Translation, London-New York: Prentice-Hall International.

Pleciński J. 2010. Neologizmy autorskie w przektadzie. Vitório Káli: ,, Terramoto” (,,Trzęsienie ziemi"), w: K. Hejwowski, (red.), Thumaczenie - leksyka, frazeologia, styl, Warszawa: Instytut Lingwistyki Stosowanej UW, s. 146-151.

Skibińska E., Rzeszotnik J. (red.) 2010. Lem i ttumacze, Kraków: Księgarnia Akademicka. Skubalanka T. 1962. Neologizmy w polskiej poezji romantycznej, Toruń: TNT.

Stockwell P. 2000. The Poetics of Science Fiction, http://www.academia.edu/724531/ The_Poetics_of_Science_Fiction (dostęp: 25.05.2019).

Suvin D. 1979. The State of the Art in Science Fiction Theory: Determining and Delimiting the Genre, „Science Fiction Studies”, 17(6), part 1, March. 